\title{
The Effect of Eliciting Tasks on Listening Comprehension among Iranian Pre-Intermediate EFL Learners
}

\section{Abdolamir Amari $^{1 *} \&$ Bahman Gorjian ${ }^{1}$}

\footnotetext{
* Correspondence:

amirammari1356@gmail.com

1. Department of English, Faculty of

Humanities, Abadan Branch, Islamic

Azad University, Abadan, Iran
}

Received: 14 February 2019

Revision: 18 April 2019

Accepted: 16 May 2019

Published online: 20 June 2019

\begin{abstract}
This study investigated the effects of eliciting tasks on listening comprehension among Iranian pre-intermediate English as a foreign language (EFL) learners. To do the current study, 30 participants out of 40 were selected through administering an Oxford Quick Placement Test (OQPT). After that, the participants were divided into two equal groups; one experimental and one control group. Then, a listening comprehension pretest was administered to assess the participants' listening comprehension at the beginning of the course. The experimental group received the treatment through eliciting tasks. Then, the control group received common instruction and was engaged in the ordinary program of the classroom. After twelve sessions of instruction, a post-test of listening comprehension was administered to gather the sufficient data. Data were analyzed through independent and paired samples t-tests and the results indicated that both experimental and control groups had better performance on their post-test compared to their pre-test. More importantly, the results showed that there was a significant difference between the post-tests of both groups. In fact, the experimental group outperformed the control group on the post-test thanks to eliciting tasks activities. The study has implications for language teachers and learners; e.g., Eliciting tasks help to develop a learner-centered classroom and a simulating environment while making learning memorable by linking new and old information.
\end{abstract}

Keywords: listening comprehension, task-based language teaching, eliciting task 


\section{Introduction}

In the last four decades, English has become the most important foreign language in the world. On the one hand, it is the language for international communication, advertising, science, commerce, intercultural connecting, diplomacy and transmitting, advanced technology, international travel and entertainments. In Iran, like in many other countries, there is a strong tendency toward learning/developing grammar ability in a foreign language, e.g., English. Therefore, in learning English for both foreign and second language, the learner should master the four essential skills namely listening, speaking, reading, and writing in order to comprehend and utilize the language accurately. These skills cannot stand-alone; in other words, one skill will support the other skills (Afandi, Jufrizal, \& Narius, 2013). Thus, the learners cannot learn only one single skill. Moreover, in teaching and learning English, there are some sub-skills included in the four skills such as vocabulary, pronunciation, and grammar.

Generally, when we learn a language, there are four skills that we need for complete communication. When we learn our native language, we usually learn to listen first, then to speak, then to read, and finally to write. These are called the four language skills (Ahmad, 2016). The recent studies have shown that teaching skills and elements of language results in a better learning outcome because skills and elements of the language are mutually enhanced. Besides, in skill integration approaches, listening as the first skill is focused in both EFL and English as a second language (ESL) contexts (Pourhossein Gilakjani \& Ahmadi, 2011). Listening is considered as Cinderella skill in second language learning. Unfortunately, it has been overlooked by its elder sister: speaking. For most people, being able to claim knowledge of a second language means being able to speak and write in that language. Listening and reading are therefore secondary skills means to other ends, rather than ends in themselves. Throughout 1960s, oral language skills were emphasized and it became fashionable again in the 1980s when Krashen's (1982) ideas about comprehensible input gained prominence. During those days, proponents of listening in a second language were also encouraged by work in the first language field.

Brown (1990) demonstrates the importance of developing oral language (the ability to listen and speak) as well as literacy, in school. Prior to this, it was taken for granted that first language speakers needed instruction in how to read and write, but not how to listen and speak because these skills were automatically designated to them as native speakers. As the basic step, it seems to be necessary to define listening as a cornerstone of language learning (Ahmad, 2016). Rost (2009) defines listening as a process of understanding what is heard and organizing it into lexical elements to which meaning can be allocated. He demonstrates that students hear oral speech, divide sounds, classify them into lexical and syntactic units, and comprehend the message. Listening is a process of receiving what the speaker says, making and showing meaning, negotiating meaning with the speaker, and answering and creating meaning by participation, creativity, and empathy. Osada (2004) expresses that listening skill did not receive sufficient acceptance in its own right.

According to Jafari and Hashim (2015), listening involves auditory discrimination, aural grammar, selecting necessary information, remembering it, and connecting it to the process between sound and form of meaning and they emphasized that listening is a channel for comprehensible input and more than 50 percent of the time learners spend in learning a foreign language is devoted to listening. Hamouda (2013) defines listening comprehension as an interactive process in which listeners are involved in constructing meaning. Also, listening comprehension means that a person understands what he/she has heard. If he/she learns the text through hearing it, he/she will understand it. Additionally, listening comprehension is the product of teaching methodology and is matched by terms such as speech understanding, spoken language understanding, speech recognition, and speech perception. Moreover, in recent decades, language researchers have come to believe that getting learners involved would help accelerate the process of learning. In this process, the four main skills -speaking, listening, reading, writing-are closely linked, meaning that they can reinforce or to be reinforced by each other. Among these four, this study considers listening comprehension.

Regarding improving listening comprehension, there are some tasks. Tasks are stimulating for learners and they involve students in learning process. In EFL/ESL research, tasks have been widely used as useful tools to elicit language production, interaction, negotiation of meaning, processing of input and focus on form, all of which are believed to develop foreign language learning (Nunan, 2004). Prabhu (1987) defines a "task" as an activity which requires learners to arrive at an outcome from given information through some process of thought, and which allows teachers to monitor and regulate that process. Eliciting (elicitation) tasks are tasks which describe a range of techniques which enable the teacher to get learners to provide information rather than giving it to them. Commonly, eliciting is used to ask learners to come up with vocabulary and language forms and rules, and to brainstorm a topic at the start 
of a skills lesson. The term is defined in the Dictionary of Language Teaching and Applied Linguistics as techniques or procedures which a teacher uses to get learners to actively produce speech or writing, suggests that there may be wider applications.

Skehan (1998) says that task is "an activity in which meaning is primary; there is some communication problem to solve; there is some sort of relationship to comparable real-world activities; task completion has some priority; and the assessment of task performance is in terms of task outcome" (p. 95). The eliciting tasks were utilized in this study in order to improve the students' listening comprehension. Eliciting task is a term which describes a range of techniques like understanding the language forms, meanings and functions which enable teachers to provide the learners with eliciting information for appropriate conversation (Rose \& Ono, 1995). Eliciting tasks help to develop a learner-centered classroom and a simulating environment while making learning memorable by linking new and old information. Eliciting is not limited to language and global knowledge. The teacher can elicit ideas, feelings, meaning, situations, associations, and memories. For the teacher, eliciting tasks is a powerful diagnostic tool, providing the learners with key information about what the learners know or do not know which a starting point is for lesson planning.

\subsection{Statement of the Problem}

Although listening can serve as the main base to other aspects of language learning, it has been notoriously neglected in public schools of Iran. Despite the importance of listening comprehension, in language institutes and high schools of Iran, English language classes still stress other skills rather than listening skill. Chastain (1988) believes "both language teachers and students tend to overlook the importance of listening comprehension skills since their attention is fixed so completely on their ultimate goal, speaking that they fail to recognize the need for developing speaking skills" (p. 192). Since Iranian EFL learners do not have any opportunity to communicate with native speakers to practice listening, so it's usual that they might have listening comprehension problems. In addition, since Iranian students are not exposed to comprehensible listening input in their classes or in real world, this skill has not been nurtured. So, teachers must find ways to help English learners improve their listening skills. Tasks are also overlooked in Iranian high schools. As learning by doing helps learners improve the language proficiency, it has not received the attention it deserves. So, the current research tried to cover these issues, hoping it would be a step to enhance Iranian EFL learners' listening comprehension.

\subsection{Objectives of the Study}

Listening can serve as the main gate to other aspects of language learning, but it has been notoriously neglected in public schools of Iran (Safdarian, 2012). As students' intake precedes their production, listening can be the prerequisite to other skills that should be taken seriously. Therefore, two major objectives were followed in the current study; firstly, this study tried to figure out if eliciting tasks have any effects on improving Iranian EFL learners' listening comprehension. Secondly, the present study aimed to find out whether there is any significant difference between the listening comprehension of Iranian EFL learners who use eliciting tasks and those who use traditional activities.

\subsection{Research Questions and Null Hypotheses}

To fulfill the purposes of the study, the following research questions were formulated:

RQ 1. Do eliciting tasks have any significant effect on improving Iranian EFL learners' listening comprehension?

RQ 2. Is there any significant difference between pre-intermediate EFL learners who use eliciting tasks in learning listening comprehension and the learners who are taught traditionally?

To investigate the above-mentioned research questions empirically, the following null hypotheses were made:

H0 1. Eliciting tasks do not have any significant effect on improving Iranian EFL learners' listening comprehension.

H0 2. There is not any significant difference between pre-intermediate EFL learners who use eliciting tasks in learning listening comprehension and the learners who are taught traditionally.

\subsection{Significance of the Study}

The findings of this study can promote teaching listening through applying eliciting tasks. Furthermore, this study can pave the way for further related studies, so the researcher hopes it can be a reference for the other researchers who aim to do more experimental studies in teaching listening. Practically, this study was carried out to figure out the 
effectiveness of using eliciting tasks in teaching listening. They would be implemented in the class to give more opportunities to the students to be more active in sharing their knowledge. Besides, this study would motivate students to be confident to represent their idea, opinion, and feeling through receiving input and then producing output. The findings of this study would provide rich insights for second/foreign language teachers and syllabus designers in the target language teaching process. First of all, teachers can gain profits from the results and try to utilize eliciting tasks while teaching. All language teachers are invited to assigning eliciting tasks which are popular and adaptable frameworks in language teaching. Carrying out different types of tasks influences students' progress and attitudes towards learning L2. Whenever students are given tasks that involve them completely, their promotion is observed. Learners prefer to be active receivers, rather than passive ones. So, teachers should not ignore the motivating aspect of learners' involvement.

\section{Review of the Literature}

\subsection{Task-based Language Teaching}

For many years, task-based language teaching (TBLT) got a lot of attention of second language acquisition (SLA) researchers, teachers, curriculum developers, and teacher trainers (Branden, 2006). The SLA researchers and language instructors made a term, because of standard based SL classroom exercises (Long \& Norris, 2000). Long (1985) and Prabhu (1987) supported a system in which learners experience functional tasks that let them focus on significant undertakings and language use (Branden, 2006). In the TB guideline, the point is to make a prerequisite to learn and utilize. The errands will make their own language and produce a chance for learning language unequivocally. Willis and Willis (2007) have made an endeavor-based structure. This undertaking-based system making an association between the language errands and educational unit incorporates three segments and some sub-parts (Willis \& Willis, 2007). According to this structure, educators do not make the structures to be taught and the vocabulary to be secured in a unit; however, they utilize tasks to accomplish a few finishes, as per the understudies' needs and supports. In addition, it may go past the customary technique for setting dialect direction presented by Skehan (1998) as the (PPP), Presentation, Practice, and Production (Eliss, 2003). There are a few points of interest to this structure. This system moves past the idea of evaluation in a traditional perspective. TBLT structure can help instructors and understudies have open doors for correspondence. This methodology must be used with the three components including language mindfulness, the intercultural skill, and the content-based methodology.

In commencing the discussion about TBI, it seems crucial to specify what is meant by task. Various definitions are presented for what a task is; for example, Bialystok (1981, p. 103) suggests that a communication task must "a) stimulate real communicative exchange, b) provide incentive for the L2 speaker/learner to convey information, c) provide control for the information items required for investigation, and d) fulfill the needs to be used for the goals of the experiment." Nunan (1989) divides task types into two broad categories of real-world/target tasks (e.g., using telephone) that refer to the uses of language in the real world and pedagogic tasks (e.g., information gap activities) that happen in the classroom (Nunan, 2004). Edwards and Willis (2005) declare in TBLT, tasks compose the main component in the language classroom because they provide better contexts for activating learner acquisition process and promoting L2 learning. Richards and Rodgers (2001) mention because "tasks are believed to foster processes of negotiation, modification, rephrasing, and experimentation that are at the heart of second language learning" (p. 228). It can be concluded that TBLT is based on a theory of language learning rather than a theory of language structure.

\subsection{Tasks and Learning}

Because task-based work involves holistic language processing, it can generate a rich range of learning processes (Long, 2009). One is the process of relating the language user's intention to meaning, and meaning to linguistic form. That is, in order to achieve task goals, during task communication, students identify relevant meanings, and try to map them to relevant words and phrases; indeed, much learning occurs by association, simply through exposure to language input that has not been disarticulated from context, content, and purpose (i.e., the holistic task). This leads learners to explore relationships between words and meanings, interrelating meanings and appropriate language, and learning how to do things with words. This is the core of a TBLT approach; in particular, contextually relevant meanings are the reference point for developing implicit and explicit understanding of new language. This process often requires engaged interlocutors signaling whether they have understood or not. Successful communication is a proof that learners have learned how to use parts of the language; unsuccessful communication is an opportunity for them to identify gaps in their knowledge, so they can find ways of filling them. Communication as a learning process thus 
requires a willingness to negotiate meaning, both referential (denoting concepts) and pragmatic (impacting other people's behaviors and attitudes).

Importantly, such negotiation can generate feedback on language gaps at the precise moment and context where learners need to learn. Researchers (Mackey, 2008) have found that negotiation for meaning and other interactional moves such as scaffolding, recasting, and error corrections can lead to effective learning, and that improved memory for vocabulary, grammar, and even pragmatics can be positively related to successful interaction between learners. In a similar vein, those working from a more socially grounded orientation (Mackey \& Polio, 2009) have noted how by working jointly on tasks, learners can contribute mutually to each other's learning. It follows that the teacher too can play an important role in negotiation for meaning and broader interaction processes. Task work can also help develop learners' fluency, complexity, accuracy, and appropriacy of language use. Research (Robinson, 2011; Skehan, 2014) showed that learners' attention can be drawn differentially to fluency, complexity, or accuracy in their performance with language by varying the kinds of task. Certain kinds of relatively simple tasks may tend to prioritize accuracy and fluency in performance, while more complex tasks (e.g., containing unstructured content or multiple elements to deal with) may lead to more grammatically complex, less fluent, and less accurate language, thereby helping to push inter-language development (Robinson, 2011). Task conditions are also influential: pre-task planning time can lead to greater complexity and fluency but less accuracy, whereas lack of time pressure results in greater accuracy.

Repeating tasks can enable learners successively to increase their complexity, accuracy, and fluency. Although research is not as yet definitive regarding the details, these features of tasks offer teachers and material developers clear opportunities to influence learners' attention to particular aspects of language use through the selection and manipulation of task designs. Finally, task-based learning has implications for other types of language learning. Experience of working with a particular task can provide a starting point for relevant "off task" learning-checking vocabulary, clarifying grammatical features, exploring pragmatic expressions-or pronunciation practice: form-focused work is made valuable by prior experience of the task and of trying to complete it (Skehan, 2014).

\subsection{Significance of Tasks in Language Learning}

In recent decades, it has been approved that applying different tasks in the classroom is helpful. In this regard, Azar and Maragheh (2012) asserted that task-based learning has become more popular and famous, and suggested that it can be regarded as a way forward in ELT. Prabhu (1987) defined a task as an activity which requires students to achieve an outcome from available information through some process of thought, and which allows teachers to monitor and regulate that process. According to Willis (1996), tasks are activities in which the students use the target language for a communicative purpose to attain an objective. Bygate, Skehan, and Swain (2001) stated that a "task" is an activity that requires learners to use language, with emphasis on meaning, to arrive at an outcome. Based on the mentioned definitions, task is an activity that requires language learners to use the language through a communicative purpose to attain an objective. Moreover, meaning is the major focus rather than form. Ellis (2003) mentioned six main features of a task:

1. A task is a work plan. A task constitutes a plan for learning activity. This work plan takes the form of teaching materials. The actual activity that results may or may not match that intended by plan.

2. A task involves a primary focus on meaning. A task seeks to engage learners in using language pragmatically rather than displaying language. It seeks to develop L2 proficiency through communicating. Thus, it requires a primary focus on meaning.

3. A task involves real-world processes of language use. The work plan may require learners to engage in language activity such as that found in the real-world, for example, completing a form, or it may involve them in language activity that is artificial, for example, determining whether two pictures are the same or different.

4. A task can involve any of the four language skills. The work plan may require learners to (1) listen or read a text and display their understanding, (2) produce an oral or written text, or (3) employ a combination of receptive and productive skills.

5. A task engages cognitive processes. The work plan requires learners to employ cognitive processes such as selecting, classifying, ordering, reasoning, and evaluating information in order to carry out the task. 
6. A task has a clearly defined communicative outcome. The work plan stipulates the non-linguistic outcome of the task, which serves as the goal of the activity for the learners. The stated outcome of a task serves as the means of determining when participants have completed a task.

Moreover, in language teaching, in order that tasks be useful in providing a rich context for promoting learners' knowledge and skills, and integrate improving fluency and accuracy, they should be employed systematically (Bygate, 1999). Utilizing TBI and authentic materials accelerate students' progress and enable them to apply effectively their new FL in real world (Prabhu, 1987; Skehan, 1996). Ellis (2003) mentions key characteristics of an effective two-way collaborative task as: 1) a focus on meaning (rather than on language form), 2) selection by the learner to select the needed linguistic resources for completing task (rather than on all resources all provided to the learner), and 3) a palpable outcome (that is assessable for its correctness or appropriateness). These features promote collaborative learning, active listening, negotiation of meaning, and attention to feedback. Consequently, these features are crucial for developing learner uptake during the task, rather than sole completion of the task (Carroll \& Swain, 1993; Gass, 1997). Bygate (1999) proclaims that a pedagogical task promotes learning through establishing demands, and on communication tasks, the demands are communication problems that need to be solved through employing language. Language and processing exist alongside and using tasks promote learning, i.e. developing both language content and processing abilities. According to Ellis (2003), a task can involve any of the four language skills including listening comprehension ability. Listening tasks can be applied for various purposes: 1) measuring whether learners have acquired a special feature targeted to be learned or facilitating learning a special feature through modifying the input for effective processing the feature, 2) providing a non-threatening way to engage learners in a meaning-centered activity, and 3) providing learners with the enriched input. In listening-to-comprehend tasks, learners use their schematic knowledge to carry out the task (Ellis, 2003).

\subsection{Eliciting Tasks}

Eliciting task is a term that describes a range of techniques like understanding the engage forms, meanings and functions that enable teachers to provide the learners with eliciting information for appropriate conversation (Rose \& Ono, 1995). Eliciting tasks help to develop a learner-centered classroom and a simulating environment while making learning memorable by linking new and old information. Eliciting is not limited to language and global knowledge. The teacher can elicit ideas, feelings, meaning, situations, associations, and memories. For the teacher, eliciting tasks is a powerful diagnostic tool, providing the learners with key information about what the learners know or do not know which a starting point is for lesson planning (Rose \& Kasper, 2001). Eliciting tasks also encourage teachers to be more flexible rather than dwell on information that is already known (Brown, 2007). The success of eliciting depends largely on the attitudes of teachers and learners to their respective roles. Ideally, it promotes the notion of an exchange of information, helps to break down traditional teacher-centeredness, and begins to establish a variety of interaction patterns in the classroom. It is also fundamental to the inductive approach to teaching language and to learning through tasks and self-discovery, and a simple and effective way of getting learners to produce language (Newton, 1993).

Furthermore, eliciting task refers to teaching a second/foreign language that seeks to engage learners in an authentic language use by having them perform a series of tasks. It aims to both enable learners to acquire new linguistic knowledge and to process their existing knowledge (Ellis, 2003). The main characteristics of eliciting tasks are the following (Ellis, 2003):

a) Natural or naturalistic use of language,

b) Learner-centered rather than teacher-controlled learning,

c) Focus on form (attention to form occurs within the context of performing the task; intervention while relating naturalness),

d) Tasks serve as the means for achieving natural use of language, and

e) Traditional approaches are ineffective. 
Eliciting is based on several premises:

- Collectively, students have a great deal of knowledge, both of the language and of the real world. This knowledge needs to be activated and used constructively,

- The teaching of new knowledge is often based on what the learners already know, and

- Questioning assists in self-discovery, which makes information more memorable.

In fact, eliciting means extract or pull out if one asks someone indirect and sometimes direct questions to make him/her say what he does not know.

\subsection{Listening Comprehension}

Listening is "the activity of paying attention to and trying to get meaning from something we hear (Underwood, 1989, p. 12)." Mendelsohn (1994) defined listening comprehension as the ability to understand the spoken language of native speakers. O’Malley, Chamot, and Kupper (1989) also provided a good definition of listening: "Listening comprehension is an active and conscious process in which the listener constructs meaning by using cues from contextual information and from existing knowledge, while relying upon multiple strategic resources to fulfill the task requirement" (p. 19). Byrne (1986) considered listening as an active process; he added that when one listens to his mother tongue, understanding normally seems effortless because the experience of the spoken language is enormous. He mentioned that when going back to the time when one was born, s/he was exposed to quantities of language and different speakers, and variety of topics. Because of that experience, the listeners can easily identify the message, phonological and grammatical patterns, and lexical items. Secondly, the experience of language caused the awareness of all factors that help to predicate what is likely come next. Thirdly, there are a number of contextual clues to help the teacher in listening comprehension to know about the participants, the setting, the topic, and the purpose. Not all listening situations are easy, especially when one cannot see the speaker(s) particularly facial expression, for example, as on the telephone it required more than concentration to understand the topic. He added that the length of time of listening without participating may cause memory problems.

Fang (2008) stated that listening is the Cinderella skill in second language learning. It became fashionable again in the 1980s when Krashen's (1982) ideas about comprehensible input gained prominence. Richards (1987) said that the idea about the comprehensible input gained prominence that requires negotiation of meaning and which contains linguistic features a little beyond the learner's current level of competence. As Rost (1994) pointed out, of the four language skills; speaking, listening, reading, and writing, listening is the most critical for language learning at the beginning stages. Large amounts of listening practice before speaking or reading may prepare the learner to acquire a second language with a greater efficiency than if s/he was taught all the skills simultaneously. In fact, listening is the most frequently used language skill in everyday life. Actually, people in general listen twice as much as they speak four times as much as they read, and five times as much as they write. Listening is a highly integrative skill. Listening is assuming greater and greater importance in foreign language classrooms. When one thinks of learning a language, s/he should consider four basic skills: listening, speaking, reading, and writing. Listening is listed first not only because it appears first in natural first language acquisition but because it is used the most.

Morley (2001) cited that listening was often classified as one of the skills of reception rather than production like speaking, making it seem a passive skill. However, as Rivers (1981) pointed out listening comprehension is a very active skill. Far from being an act of reception, it involves the construction of a message from phonic material. To conclude, listening comprehension skills should be discussed under two related headings. Firstly, the processing sounds by which the listener can recognize word utterance, sentences recognize significance of languagerelated features such as intonation, pitch, and tone. Secondly, the processing meaning by which the listener can organize the heard speech into meaningful sections, to identify the language data to understand what speakers are going to say, and to store information in memory and know how to get them back later by organizing meaning and details. Furthermore, according to Underwood (1989 as cited in Abdalhamid, 2012), listening means "the activity of paying attention to and trying to get meaning from something we hear (p. 12)". Mendelsohn (1994) defines listening comprehension as the ability to understand the spoken language of native speakers. O'Malley, Chamot, and Kupper (1989) also provide a good definition of listening: "Listening comprehension is an active and conscious process in which the listener constructs meaning by using cues from contextual information and from existing knowledge, while relying upon multiple strategic resources to fulfill the task requirement (p. 19)". 
Listening is a psychological phenomenon which takes place on a cognitive level inside people's heads, and a social phenomenon which develops interactively between people and the environment surrounding them. Listening is considered as a complex process which needs to be understood in order to teach it and subsequently evaluate it before integrating it with phonological aspects and with the skill of speaking (Bueno, Madrid, \& McLaren, 2006). As we know, listening is the skill of understanding spoken language. Listening is an essential skill, present in most of the activities we carry out throughout our lives, as Lindsay and Knight suggest (2006): We listen to a wide variety of things, for example; what someone says during a conversation, face to face or on the telephone; announcements giving information, for example, at an airport or railway station; the weather forecast on the radio; a play on the radio; music; someone else's conversation (eavesdropping); a lecture; professional advice, for example, at the doctor's, in the bank; instructions, for example, on how to use a photocopier or other machinery; directions; a taped dialogue in class.

\subsection{Listening Tasks and Activities}

Byrne (1986) stated a number of possible activities and key areas of listening tasks, for instance, the teacher should concentrate on such things like ears training in distinguishing between key sounds, stress, and intonation patterns. Additionally, on game-like activities by which several language games depend for their success on students' listening carefully to one another. Also, giving instruction to students obliged them to listen carefully in order to arrive to a particular place. In completion type activities, learners have to complete an incomplete version of a story, description or a song by words, phrases or sentences during listening or afterwards. Identifying mistakes or contradictions is the next activity that helps the teacher in teaching listening, the learners here listen to a description of any object, person or place they have to note any mistakes. Then, there are additional activities, finding difference, students listen to two versions of a story and they have to mention the differences (Byrne, 1986). Problem-solving may help the teacher in teaching listening, learners listen to three or four people, places, events, and listen to one of these being described. Learners here have to decide which item is being talked about or they may be asked to categorize items mentioned in a conversation or discussion.

Finally, extracting information is the commonest type of listening tasks. In this task, the learners will need a chart to fill in, for example if learners listen to a conversation between two speakers discussing a shopping expedition, the teacher may ask the learners to make notes in the form of a shopping list. Some teachers think that listening is the easiest skill to teach, whereas most students think it is the most difficult to improve. This contradiction warns teachers that there are some things about teaching listening that need to be investigated. Maybe those who claim it is the easiest to teach may say that it does not need much laborious lesson preparation and all they are required to do is to play the tapes and test the students' comprehension. But is not there really anything more to teaching listening than testing? One must discover all we can about how listening can be enhanced and what activities are useful to this purpose and then fully make use of this knowledge and these activities in the classroom (Byrne, 1986).

\subsection{Experimental Background}

Some studies were conducted regarding the effects of tasks on learning language; some of them are reported in this part. Farrokhi and Modarres (2012) attempted to find out the extent to which two pre-task activities of glossary of unknown vocabulary items and content related support assisted EFL language learners with their performance on listening comprehension questions across low proficiency (LP) and high proficiency (HP) levels. Each level consisted of three groups, two experimental groups and one control group (twenty participants in each group). One experimental group received "glossary of unknown vocabulary items" with the pronunciations while the other group received content related support (in written form) with the aim of activating prior knowledge before administering post-lecture listening comprehension questions. The statistical analysis of the data revealed that in low proficiency level, vocabulary group outperformed both content and control groups while in high proficiency level, content group outperformed the other groups. The study concluded by suggesting that pre-task activities need to be used taking account of the support type and the learners' proficiency level.

Motallebzadeh and Defaei (2013) aimed at exploring the role of task-based listening activities in augmenting EFL learners' listening self-efficacy. To this end, 70 male and female Iranian EFL learners in Kish Air English Institute, Mashhad, Iran participated in the study. To homogenize the participants' level of proficiency, the Interchange/Passages Objective Placement Test was employed and the participants with the intermediate level of proficiency were selected. Accordingly, the number of the participants was reduced to 50. To measure the participants' level of listening self-efficacy at the pre- and post-tests, a listening self-efficacy questionnaire (20 items) was applied. Then, the participants were randomly divided into two groups: experimental $(\mathrm{N}=26)$ and control $(\mathrm{N}=24)$. The 
experimental group received task-based listening activities during the 19 sessions (30 minutes) of instructions, and the control group received the traditional practices (a question-and-answer approach). The results of independent $\mathrm{t}-$ test revealed that the participants' levels of listening self-efficacy in the experimental group was significantly higher than those in the control group $(\mathrm{P}=0.05)$.

Khoshsima and Sadighi Tasu (2014) investigated the difference of five task types applied in Task-Based Instruction (TBI) on intermediate-level EFL learners' listening comprehension ability. To this end, 31 intermediate EFL learners were given five task types of matching, selecting, role-playing, note taking, and completing. Their proficiency and listening homogeneity was ensured using an institutional Test of English as a Foreign Language (TOEFL) test and the listening paper of FCE. Then, they enjoyed TBI through implementing the task types for about ten 20-minute sessions. The results of the different tasks were analyzed to find out what task was the most effective. The results indicated that the learners outperformed in the two tasks of note-taking and completing than in the first three tasks of matching, selecting, and role-playing, but there was no significant difference among the three tasks of matching, selecting, and role-playing ( $p>0.05)$, neither was there any significant difference between the two tasks of note-taking and completing $(\mathrm{p}>0.05)$.

Moreover, Zohrabi, Sabouri, and Behgozin (2015) clarified the listening skill as an area of pivotal skill by investigating the effect of pre-listening activities on Iranian EFL learners' listening comprehension of authentic English movies. Based on this aim, sixty intermediate EFL learners from a language institute were selected and randomly assigned into two groups. One group was exposed to and received authentic listening input (experimental group) and the other group received simplified listening materials (control group). A proficiency test (including two sub-tests, listening comprehension and listening perception) was used as a pre-test to measure the learners' potential differences at the beginning of study. After the instruction session, a post-test was administrated to both groups. The analysis of the quantitative data and comparison of the mean scores of the two groups via post-test showed that the learners who were exposed to pre-listening activities performed better in the post-test. Moreover, the analysis of feedback indicated the positive effect of pre-listening activities on the EFL learners' listening comprehension of authentic English movies.

Recently, Gorjian and Pourkaram (2018) investigated the effect of pragmatic eliciting tasks on EFL pre-intermediate learners speaking proficiency. This study aimed at comparing the English language learners who practiced pragmatic eliciting tasks and the ones who used traditional speaking activities such as questions and answers, discussion, etc. In doing so, 40 learners out of 80 were selected through Oxford Quick Placement Test (OQPT) with the band score of 30 to 39 . Then they were non-randomly divided into two equal experimental and control groups through convenience sampling method. Both groups took a teacher-made pre-test on speaking proficiency and the scores were recorded. The experimental group received pragmatic eliciting tasks including explicit uses of pragmatic functions of speech (i.e., greeting, thanking, etc.) while the control group received these pragmatic tasks implicitly. Finally, both groups took a post-test which was the modified pre-test. Data were analyzed through independent and paired sample $t$-tests and the results showed that explicit instruction on pragmatic eliciting tasks were effective than the implicit ones in the control group.

Molavi and Kuhi (2018) investigated the comparison among the effects of three different pre-listening tasks, including lexical support, content support, and telling the main purpose of listening on the improvement of learners' listening comprehension at intermediate and advanced levels. To meet the objectives of the study, four classes from each level were selected and randomly assigned into one control and three experimental groups. Each experimental group was given one kind of pre-listening task before the post-tests. One-way ANOVA was used to analyze the data. After scoring the tests and analyzing the mean scores, significant differences were found among the effects of the three pretasks. The most facilitative pre-listening tasks at intermediate and advanced levels were lexical support and content support, respectively. Informing the learners of main purpose of listening was the least effective pre-task at both levels. It can be concluded that there might be no one single kind of pre-listening task appropriate for all learners. A variety of factors such as context of instruction, learners' ages, and their proficiency levels can affect the teacher's choice of pre-task types.

\section{Methodology}

\subsection{Design of the Study}

Quasi- experimental method of research was used in this study. Accordingly, the study employs a pre-test and posttest design to extract needed data of one experimental group and one control group. This study focused on the variable 
of eliciting tasks as an independent variable and listening comprehension as a dependent variable which is hypothesized to be affected by the independent variable. The collected data will be analyzed quantitatively through using paired and independent samples t-tests.

\subsection{Participants}

To do this study, thirty-pre-intermediate level participants from Arvand Language Institute in Khoramshahr were chosen among 40 volunteers. Their proficiency level was estimated through the Oxford Quick Placement Test (OQPT). They were all male students and monolingual aged between 13 and 16 . The selected participants were nonrandomly divided into two groups namely control and experimental, each group contains 15 participants. The researchers selected all the participants from male students because they could access them more easily. The experimental group received the treatment, which was teaching and learning listening through eliciting tasks. The control group just received placebo. The classes were conducted in the afternoon twice a week; each session lasted about 70 minutes.

\subsection{Instruments}

In order to accomplish the objectives of the present study, the following instruments were employed:

\subsubsection{Oxford Quick Placement Test}

Initially, a placement test was taken to determine the proficiency level of learners. This was carried out through the administration of Oxford Quick Placement Test. The test consisted of 60 items that were to be answered in 70 minutes. It comprised of two parts (Part one and Part two). There were different forms in this test such as multiple choice, item matching, and cloze test type items in the test. In each item, there were four options for a missing word. Students were asked to find the correct item among these options.

\subsubsection{Teacher-made Pre-test}

The second instrument for gathering information was a teacher-made listening pre-test designed based on the students' materials. It was a listening comprehension test of 40 objective items. It included filling the blanks and multiplechoice items. It addressed the students' background knowledge in their English listening comprehension. It was designed in advance by the researchers through a pilot study on a small group of the learners other than the participants of the study. The researchers piloted the test in another institute on the similar group to ensure the test reliability. The reliability of test was calculated by using Cronbach's alpha formula as $(\mathrm{r}=0.898)$. To get sure about the validity of the test, opinions of two teachers were obtained to arrive at the content validity. The allotted time was 50 minutes and the correct answer to each item received one point. There was no penalty for false responses.

\subsubsection{Teacher-made Post-test}

The third instrument utilized in this study was a teacher-made listening test. It was a modified version of the pre-test that was used as the post-test. It was given to the participants to measure the impacts of eliciting tasks on their listening comprehension skill. In fact, the same test was used twice, once as a pre-test and once as a post-test instrument. All characteristics of the post-test were the same as those of the pre-test in terms of time and the number of items. The only difference of post-test from the pre-test was that the order of questions and alternatives were changed to avoid recalling of the pre-test answers.

\subsection{Data Collection}

At first, 30 pre-intermediate students were selected through the administration of OQPT. They were randomly divided into experimental and control groups. As mentioned in previous sections, each group was composed of 15 learners. Next, both groups took a listening pre-test and it was checked against validity and reliability measures. The test consisted of 40 items and asked the learners to choose the correct choice and fill in the blanks. The pre-test checked the participants' knowledge of listening comprehension in both groups. Afterwards, the experimental group received the treatment which was teaching listening comprehension through eliciting tasks. In eliciting tasks, the researchers got information about what the students know and do not know. This means that the teacher became more capable and did not waste time rehashing the students' existing knowledge. Before starting to teach a lesson, the teacher got a great deal of things such as eliciting vocabulary, grammar, synonyms, antonyms, background information, language forms and rules, general knowledge, opinions, feelings, contexts, meanings, memories, associations, ideas, situations, questions and answers. Eliciting got students involved in the lesson, because they were actively producing speech and 
giving information. The students became active learners, rather than just listening to the teacher give information. The teacher assessed the students' knowledge and in-turn adapt the lesson to the students' needs. There was a great deal of collective knowledge in a group of students and utilizing this knowledge made the teaching of new knowledge more memorable.

For eliciting vocabulary knowledge, the teacher provided the students with a definition and saw if the students could supply the correct word. The researchers also used synonyms to elicit vocabulary. When he used this technique, he made a statement and asked the students to paraphrase it by using a synonym. Using opposites (antonyms) was also useful when the teacher wanted to elicit a word from a student. Furthermore, the teacher could pretend he has forgotten the word he was trying to elicit. This happened regularly in natural conversation and was a great way to elicit vocabulary. The teacher asked the students questions to try to elicit the vocabulary she pretended he could not remember. Normally, a headline or photos were used to elicit from the students. In this way, the teacher got the students to predict the story, ideas, forms, and language that were likely to be used. Furthermore, when a lesson was topic based, it was always a good idea to get the students to give the teacher their background knowledge of the topic and their ideas. Write up any vocabulary or information they gave the teacher in the class were found useful. This collective knowledge came in handy during the lesson. The teacher was able to elicit this information by using a text, mind map or pictures. He could even tell a story or anecdote and ask for the student's reaction. In addition, brainstorming helped the students come up with ideas and information relating to the topic the teacher was going to teach. The students could work in groups or together as a class to think of words and associations relating to the topic. Free writing was also a useful activity to help draw on the students' background knowledge. The researchers asked the students to free-write for a few minutes in response to a topic or question. Students were likely drawing on experiences or knowledge to help them complete the activity.

On the other hand, the control group was engaged in the ordinary program of the classroom. The same instructor taught the participants in both groups. Finally, to ensure the effectiveness of instructions and to assess learners listening comprehension throughout the study, the pre-test was repeated at the end of the experiment, hence call post-test in the present study. The unexpected administration of the test took place in one session for both groups to find the probable differences between the two groups' performances. When the data were gathered via pre-test-post-test measures, it was time to carry out the analysis.

\subsection{Data Analysis}

The collected data through the pre and post-tests were analyzed using different statistical procedures. They were analyzed through SPSS software. Descriptive statistics such as mean and standard deviations were estimated to describe and summarize the data. The statistical analyses of paired and independent samples t-tests were run to measure the effectiveness of eliciting tasks on experimental groups' listening comprehension and to show the differences between the experimental and control groups' pre and post-tests.

\section{Results}

\subsection{Results}

In order to analyze the gathered data, the SPSS software version 17 (Statistical Package for Social Science) software was used.

Table 1. One-Sample Kolmogorov-Smirnov test (Groups' pre and post-tests)

\begin{tabular}{llrrrr}
\hline & & \multicolumn{1}{c}{$\begin{array}{c}\text { Exp. } \\
\text { Pretest }\end{array}$} & $\begin{array}{c}\text { Exp. } \\
\text { Posttest }\end{array}$ & $\begin{array}{c}\text { Cont. } \\
\text { Pretest }\end{array}$ & \multicolumn{1}{c}{$\begin{array}{c}\text { Cont. } \\
\text { Posttest }\end{array}$} \\
\hline $\mathrm{N}$ & & 15 & 15 & 15 & 15 \\
\hline Normal Parameters ${ }^{\mathrm{a}, \mathrm{b}}$ & Mean & 11.4667 & 18.3333 & 11.3667 & 14.5667 \\
& Std. & 4.44597 & 1.24881 & 4.29479 & 2.21090 \\
& Deviation & & & & \\
\hline $\begin{array}{l}\text { Most Extreme } \\
\text { Differences }\end{array}$ & Absolute & .125 & .225 & .099 & .197 \\
\cline { 2 - 6 } & Positive & .110 & .148 & .083 & .124 \\
\hline
\end{tabular}




\begin{tabular}{|c|c|c|c|c|}
\hline Negative & -.125 & -.225 & -.099 & -.197 \\
\hline Test Statistic & .125 & .225 & .099 & .197 \\
\hline Asymp. Sig. (2-tailed) & $.200^{\mathrm{c}, \mathrm{d}}$ & $.060^{\mathrm{c}}$ & $.200^{\mathrm{c}, \mathrm{d}}$ & $.122^{\mathrm{c}}$ \\
\hline \multicolumn{5}{|l|}{ a. Test distribution is Normal. } \\
\hline \multicolumn{5}{|l|}{ b. Calculated from data. } \\
\hline c. Lilliefors Significance Correction. & & & & \\
\hline
\end{tabular}

In data analysis, first, the normality of distribution was investigated. For normality, Kolmogorov-Smirnov (K-S) test was used. According to Table 1, distribution of all scores on pre-tests and post-tests is normal $(p>.05)$. Consequently, the parametric statistics like independent samples t-test and paired samples t-test can be run to get the results.

Table 2. Group statistics (Pre-test of both groups)

\begin{tabular}{cccccc}
\hline & Groups & N & Mean & Std. Deviation & Std. Error Mean \\
\hline \multirow{2}{*}{ Pretest } & Experimental Group & 15 & 11.4667 & 4.44597 & 1.14795 \\
\cline { 2 - 6 } & Control Group & 15 & 11.3667 & 4.29479 & 1.10891 \\
\hline
\end{tabular}

In Table 2, the descriptive statistics of both groups are presented. The means of both groups are almost equal. The Experimental Group's mean score is 11.4667 and the Control Group's mean score is 11.3667. This means that both groups are somehow similar since they are homogeneous at the beginning of the treatment. Therefore, the difference between the groups seems not significant on the pre-test. To be sure, whether the difference is significant or not, an independent samples t-test was run in the following table.

Table 3. Independent Samples T-test (Pre-test of both groups)

\begin{tabular}{|c|c|c|c|c|c|c|c|c|c|}
\hline & $\begin{array}{r}\text { Le } \\
\mathrm{Te} \\
\text { Equ } \\
\text { Var }\end{array}$ & $\begin{array}{l}\text { e's } \\
\text { for } \\
y \text { of } \\
\text { ices }\end{array}$ & & & t-test & Equali & of Mea & & \\
\hline & \multirow[t]{2}{*}{$\mathrm{F}$} & \multirow[t]{2}{*}{ Sig. } & \multirow[t]{2}{*}{$\mathrm{t}$} & \multirow[t]{2}{*}{$\mathrm{df}$} & \multirow{2}{*}{$\begin{array}{l}\text { Sig. } \\
(2- \\
\text { taile } \\
\text { d) }\end{array}$} & \multirow[t]{2}{*}{$\begin{array}{l}\text { Mean } \\
\text { Diffe } \\
\text { rence }\end{array}$} & \multirow[t]{2}{*}{$\begin{array}{c}\text { Std. } \\
\text { Error } \\
\text { Differ } \\
\text { ence }\end{array}$} & \multicolumn{2}{|c|}{$\begin{array}{l}95 \% \text { Confidence } \\
\text { Interval of the } \\
\text { Difference }\end{array}$} \\
\hline & & & & & & & & Lower & Upper \\
\hline $\begin{array}{l}\text { Equal variances } \\
\text { assumed }\end{array}$ & .13 & .71 & .063 & 28 & .95 & .100 & 1.59 & -3.16 & 3.36 \\
\hline $\begin{array}{l}\text { Equal variances not } \\
\text { assumed }\end{array}$ & & & .063 & 27.9 & .95 & .100 & 1.59 & -3.16 & 3.36 \\
\hline
\end{tabular}

Based on Table 3, since sig (.950) is greater than 0.05, therefore, the difference between the pre-tests of both groups is not significant at $(\mathrm{p}<0.05)$. In fact, they performed the same on the pre-test. 
Table 4. Group statistics (Post-test of both groups)

\begin{tabular}{cccccc}
\hline & Groups & $\mathrm{N}$ & Mean & Std. Deviation & Std. Error Mean \\
\hline \multirow{2}{*}{ Posttest } & Experimental Group & 15 & 18.3333 & 1.24881 & .32244 \\
\cline { 2 - 6 } & Control Group & 15 & 14.5667 & 2.21090 & .57085 \\
\hline
\end{tabular}

Table 4 displays the descriptive statistics of both groups on the post-test. The means of the groups are different. The Experimental Group's mean score is 18.3333 and the Control Group's mean score is 14.5667. This means that the experimental group performed better than the control group on the post-test.

Table 5. Independent Samples t-test (the Post-test of both groups)

\begin{tabular}{|c|c|c|c|c|c|c|c|c|c|}
\hline & \multicolumn{2}{|c|}{$\begin{array}{l}\text { Levene's Test } \\
\text { for Equality of } \\
\text { Variances }\end{array}$} & \multicolumn{7}{|c|}{ t-test for Equality of Means } \\
\hline & \multirow[t]{2}{*}{$\mathrm{F}$} & \multirow[t]{2}{*}{ Sig. } & \multirow[t]{2}{*}{$\mathrm{t}$} & \multirow[t]{2}{*}{$\mathrm{df}$} & \multirow{2}{*}{$\begin{array}{c}\text { Sig. } \\
(2- \\
\text { tailed } \\
\quad)\end{array}$} & \multirow[t]{2}{*}{$\begin{array}{c}\text { Mean } \\
\text { Differ } \\
\text { ence }\end{array}$} & \multirow{2}{*}{$\begin{array}{l}\text { Std. } \\
\text { Error } \\
\text { Differ } \\
\text { ence }\end{array}$} & \multicolumn{2}{|c|}{$\begin{array}{l}95 \% \text { Confidence } \\
\text { Interval of the } \\
\text { Difference }\end{array}$} \\
\hline & & & & & & & & Lower & Upper \\
\hline $\begin{array}{l}\text { Equal variances } \\
\text { assumed }\end{array}$ & 6.2 & .018 & 5.74 & 28 & .000 & 3.76 & .655 & 2.42 & 5.10 \\
\hline $\begin{array}{l}\text { Equal variances not } \\
\text { assumed }\end{array}$ & & & 5.74 & 22.1 & .000 & 3.76 & .655 & 2.40 & 5.12 \\
\hline
\end{tabular}

Table 5 indicates that Sig (.000) is less than 0/05, this means that the difference between the both groups is significant at $(\mathrm{p}<0.05)$. In fact, the experimental group outperformed the control group on the post-test. It can be concluded that the eliciting tasks had positive effects on the experimental group's listening comprehension.

Table 6. Paired Samples statistics (Pre and post-tests of both groups)

\begin{tabular}{cccccc}
\hline & & Mean & N & Std. Deviation & Std. Error Mean \\
\hline Pair 1 & Exp. Posttest & 18.3333 & 15 & 1.24881 & .32244 \\
\cline { 2 - 5 } & Exp. Pretest & 11.4667 & 15 & 4.44597 & 1.14795 \\
\hline Pair 2 & Cont. Posttest & 14.5667 & 15 & 2.21090 & .57085 \\
\cline { 2 - 5 } & Cont. Pretest & 11.3667 & 15 & 4.29479 & 1.10891 \\
\hline
\end{tabular}

Table 6 shows the performances of experimental and control groups who are compared in the pre- and post-test. The mean scores of the experimental group on the pre- and post-tests are 11.4667 and 18.3333 respectively. The control groups' mean scores on the pre- and post-tests are 11.3667 and 14.5667 respectively. It seems that both groups improved on their post-tests. 
Table 7. Paired Samples t-test (Pre and post-tests of both groups)

\begin{tabular}{|c|c|c|c|c|c|c|c|c|c|}
\hline & & \multicolumn{5}{|c|}{ Paired Differences } & \multirow[t]{3}{*}{$\mathrm{t}$} & \multirow[t]{3}{*}{$\mathrm{df}$} & \multirow{3}{*}{$\begin{array}{l}\text { Sig. } \\
(2- \\
\text { taile } \\
\text { d) }\end{array}$} \\
\hline & & \multirow[t]{2}{*}{ Mean } & \multirow[t]{2}{*}{$\begin{array}{c}\text { Std. } \\
\text { Deviatio } \\
n\end{array}$} & \multirow{2}{*}{$\begin{array}{l}\text { Std. } \\
\text { Error } \\
\text { Mea } \\
\text { n }\end{array}$} & \multicolumn{2}{|c|}{$\begin{array}{l}95 \% \text { Confidence } \\
\text { Interval of the } \\
\text { Difference }\end{array}$} & & & \\
\hline & & & & & Lower & Upper & & & \\
\hline Pair 1 & $\begin{array}{l}\text { Exp. Post. - } \\
\text { Exp. Pre. }\end{array}$ & 6.86 & 4.25 & 1.09 & 4.51 & 9.22 & 6.253 & 14 & .000 \\
\hline Pair 2 & $\begin{array}{l}\text { Cont. Post. - } \\
\text { Cont. Pret. }\end{array}$ & 3.20 & 5.57 & 1.43 & .115 & 6.284 & 2.225 & 14 & .043 \\
\hline
\end{tabular}

In the above table, paired samples t-test was used to compare the pre- and post-tests of each group. Since Sig (.000) is less than 0.05 , the difference between the pre-test and post-test of the experimental group is significant. Similarly, since Sig (.043) is less than 0.05 , the difference between the pre-test and post-test of the control group is also significant. It can be concluded that both groups improved from pre-test to post-test; however, the experimental group listening comprehension enhanced more than the control group thanks to using eliciting tasks.

\section{Discussion and Conclusion}

\subsection{Discussion}

After conducting different analyses, the answer of the research question was obtained. Therefore, the question of the study is answered below.

RQ 1. Do eliciting tasks have any significant effect on improving Iranian EFL learners' listening comprehension?

In this part, the first research question is answered based on the results obtained in this study. After collecting the data, the researchers analyzed them in order to find out the effectiveness of eliciting tasks on the students' listening comprehension. The findings showed that the students who received instruction through eliciting tasks had better performance compared to those who were trained through traditional classrooms. The results statistically revealed that experimental group significantly did better than the control group $(p<.05)$. Therefore, the null hypothesis of the study "Eliciting tasks do not have any significant effect on improving Iranian EFL learners' listening comprehension" was rejected. Participants in the experimental group were highly motivated to learn because of the provided eliciting tasks.

Eliciting tasks are generally found to increase motivation (Gorjian \& Pourkaram, 2018). Not only did they enjoy learning, but also they felt satisfied with what they learned. In fact, the experimental group gained higher scores on their post-test. This may be due to some appealing features the eliciting tasks have. Prabhu (1987) believed that taskbased syllabuses encourage the engagement of learners. He stated that tasks established a reasonable challenge and were cognitively motivating, as accomplishment would provide learners with a sense of achievement. Prabhu's classification of tasks rested on an account of the kinds of cognitive operations that underlie the actual performance of different kinds of tasks. It was based on the premise that using language for doing or completing a project-like task fostered acquisition-a premise that is certainly intuitively appealing. Ellis (2003) supported Prabhu's claim but considered it as an untested proposal. He stated that in the case of project-oriented tasks, where a single outcome was required in addition to a sense of security that might arise as a result of knowing that there was a definite answer to a task, language learners might show much satisfaction at the end of successful accomplishment of these types of tasks.

Throughout the learning process, the students were generally motivated for the listening eliciting tasks given by the instructor. They mostly worked in pairs and as a group. During the course procedure, the learners helped each other and engaged with the activities. The researchers were regarded as guider and facilitator in the classroom environment. He wanted to improve his students' communicative competence in engaging the task-based activities. Therefore, this helped the students to feel relaxed and comfortable throughout the process. The instructor also used non-verbal semiotic elements as body language and hand gestures in the communication circle to direct the students in the 
comprehension of tasks. The tasks that were designed for the students were typically interesting and communicative. One of the tasks was memory challenge where the students listen to the audio for only twice and they have to write some sentences, phrases or words that they can remember. It was proved to be more challenging since the students looked more enthusiastic and want to listen more and more. The other task was making questions and answers based on the text. Here, the students were mingling and exchanging the question to the other pairs. They could report because they had done that before.

Considering the results obtained from the analysis of the related data, it can be argued that the method used in teaching listening skill through using eliciting tasks in our setting were effective in the experimental group. Instructors taught skills through free discussions, letting the students sort the new words and expressions, putting them in specific groups, using them in sentences, making oral summaries, explaining language functions, using pragmatic examples of language, etc. Consequently, the language learners got familiar with interactions of language uses of intended meaning. Another reason for these results may be the focus of the experimental class on dealing with the explicit method of teaching eliciting tasks in the classroom. However, the control group dealt with implicit instruction on learning conversation on the same materials and time. In other words, both groups were significantly different in gaining scores on using eliciting tasks in their listening. The participants showed that they did not have enough knowledge in using eliciting tasks in their listening on the given topics at the beginning of the study. This result was very different at the end of the treatment period since the experimental group outperformed the control one in terms of benefiting the appropriate eliciting tasks in their listening on the post-test.

The findings of the current study are in line with Gorjian and Pourkaram (2018) who investigated the effect of pragmatic eliciting tasks on EFL pre-intermediate learners' speaking proficiency. The experimental group received pragmatic eliciting tasks including explicit uses of pragmatic functions of speech (i.e., greeting, thanking, etc.) while the control group received these pragmatic tasks implicitly. Data were analyzed through independent and paired sample t-tests and the results showed that explicit instruction on pragmatic eliciting tasks were effective than the implicit ones in the control group. The findings of this study are supported by Sarani, Zare Behtash, and Moslemi Nezhad Arani (2014) who investigated the effect of video-based tasks on improving the listening comprehension ability of Iranian pre-intermediate EFL learners. Results showed that teaching listening on the basis of video-based tasks has a significant effect on learners' listening comprehension in realizing and understanding the authentic language more effectively.

RQ 2. Is there any significant difference between pre-intermediate EFL learners who use eliciting tasks in learning listening comprehension with the learners who are taught traditionally?

In this part, the second research question is answered based on the results obtained in the study. After collecting the data, the researchers used paired and independent samples t-tests to analyze them in order to find out the effectiveness of treatment on the students' listening comprehension. The findings showed that the students who received eliciting tasks instruction had better performance compared to those who were trained through traditional instruction. The results statistically revealed that experimental group significantly did better than the control group $(p<.05)$. Therefore, the null hypothesis of the study "There is not any significant difference between pre-intermediate EFL learners who use eliciting tasks in learning listening comprehension with the learners who are taught traditionally" is rejected.

The findings imply that eliciting tasks enhanced Iranian EFL learners' listening comprehension. The findings are in line with the previous studies in cognitive psychology (Farrokhi \& Modarres, 2012; Zohrabi, Sabouri, \& Behgozin, 2015) who noted that while performing the tasks, learners engage in certain types of language use and mental processing that are useful for acquisition. They generally believed that task-based activities facilitate listening comprehension. More specifically, students' listening comprehension abilities can be improved significantly due to the effect of the teaching different task activities. Along this line, Gorjian and Pourkaram (2018) believed that, in speaking proficiency, learners use the language for a communicative purpose. Foster and Skehan's (1997) studies are in line with the results of this study. They note that students use the language to perform tasks, access information, solve problems, and talk about personal experiences; this helped them learn English more effectively.

\subsection{Conclusion}

The present study tried to measure the effect of the eliciting tasks on listening skills of Iranian students. The findings of the study revealed that although there was no significant difference in the listening comprehension of the experimental and control groups in the pre-test, there was a significant difference between both groups' mean scores 
at the end of the study in the post-test, implying a better performance of the experimental group in which the eliciting tasks were used to boost their listening comprehension. The results also indicated a significant increase in the mean score of the experimental group from the pre-test to the post-test. In this study, during 12 sessions of implementing eliciting tasks in the experimental group, the learners showed enthusiasm in taking part in classes and seemed they were more active and interested in listening than before. The students also showed that they were more involved with this new way of learning, which included different kinds of task activities, and that it caused all students to be more engaged in the process of learning. It seems that we can attribute these changes to the vital feature of eliciting tasks and the power of task-based activities, which had carried out in the process of the class.

Obviously, it is proved that task-based activities are totally effective in improving the listening ability of EFL learners. Not only looking from a teaching methodology point of view, but considering from psycholinguistics point of view, based on the present study, it gives the impression that one of the best ways of teaching and learning listening skill which is a real, actual, active, and operational approach, can be considered as eliciting tasks. In brief, although this study was limited in duration and scope, the results clearly support the findings of earlier research that favor the notion that task activities accelerate listening achievement as well as bearing positive impacts on certain important factors such as motivation and enjoying the class. This study has some implications for teachers and students. Teachers can use eliciting tasks as a warm-up technique. In addition, teachers can make the students familiar with the main tasks by requiring them to do pre-task activities. Through tasks, teachers can encourage cooperative learning among the students. The results of the study are beneficial for the students. Doing and answering the tasks can help the students to conduct the target tasks successfully. By eliciting tasks, students are involved in learning process. Students tend to be active and participate with great motivation towards tasks and activities in a class environment. Tasks offer a platform for students to display their skills through their efforts and develop them further. Language learners work and cooperate with each other in groups. When working in groups, they are able to display and produce meaningful interaction on a given topic. In addition, the class work together can assess the whole outcome of the lesson. Material developers can incorporate task-based activities and exercises in the English textbooks.

\section{References}

Abdalhamid, F. (2012). Listening comprehension strategies of Arabic-speaking ESL learners. Thesis. Colorado: Colorado State University.

Afandi, W., Jufrizal, J., \& Narius, D. (2013). The ability of the third-grade students in using different kinds of prepositions. Journal of English Language Teaching, 1(25), 625-639. http://ejournal.unp.ac.id/index.php/jelt/article/viewFile/2000/1709

Ahmad, S. R. (2016). Importance of English communication skills. International Journal of Applied Research, 2(3), 478-480. http://www.allresearchjournal.com/archives/2016/vol2issue3/PartH/2-3-47.pdf

Azar, S., \& Maragheh, T. (2012). The effect of pedagogical tasks in EFL learners' performance. MJAL, 4(3), 1-17. https://www.mjal.org/removedprofiles/2013/10.pdf

Bialystok, E. (1981). The role of conscious strategies in second language proficiency. Modern Language Journal, 65(1), 24-35. doi: 10.1111/j.1540-4781. 1981.tb00949.x

Branden, K. V. (2006). Task based language education from theory to practice. Cambridge: Cambridge University Press.

Brown, G. (1990). Listening to spoken English (2nd ed.). London: Longman.

Brown, H. D. (2007). Teaching by principles: An interactive approach to language pedagogy (3rd ed). Englewood Cliffs, NJ: Prentice Hall Regents.

Bueno, A., Madrid, D., \& McLaren, N. (2006). TEFL in secondary education. Granada: Editorial Universidad de Granada.

Bygate, M. (1999). Quality of language and purpose of task: patterns of learners' language on two communication tasks. Language Teaching Research, 3(3), 185-214. https://doi.org/10.1177/136216889900300302

Bygate, M., Skehan, P., \& Swain, M. (2001). Researching pedagogic tasks, second language learning, teaching and testing. Harlow: Longman. 
Byrne, D. (1986). Teaching oral English. England: Longman.

Carroll, S., \& Swain, M. (1993). Explicit and implicit negative feedback: An empirical study of the learning of linguistic generalizations. Studies in Second Language Acquisition, 15(3), 357-366. https://www.jstor.org/stable/44487637 doi:10.1017/S0272263100012158

Chastain, K. (1988). Developing second-language skills (3rd ed.). San Diego: Harcourt Brave Jovanocich.

Edwards, C., \& Willis, J. (2005). Teachers exploring tasks in ELT. Basingstoke: Palgrave Macmillan.

Eliss, R. (2003). Task-based language learning and teaching. Oxford: Oxford University Press.

Fang, X. (2008). Listening comprehension in EFL teaching. US-China Foreign Language, 6(1), 21-29. doi:10.17265/1539-8080/2008.01.005

Farrokhi, P., \& Modarres, V. (2012). The effects of two pre-task activities on improvement of Iranian EFL learners' listening comprehension. Theory and Practice in Language Studies, 2(1), 144-150. http://www.academypublication.com/issues/past/tpls/vol02/01/21.pdf

Foster, P., \& Skehan, P. (1997). The influence of planning and post-task activities on accuracy and complexity in taskbased learning. Language Teaching Research, 1(3), 185- 211. https://doi.org/10.1177/136216889700100302

Gass, S. (1997). Input, interaction, and the second language learner. Mahwah: Lawrence Erlbaum Associates.

Gorjian, B., \& Pourkaram, M. (2018). Interactive effect of pragmatic eliciting tasks on EFL pre- intermediate learners' speaking proficiency. International Journal of Foreign Language Teaching \& Research, 6(21), 121-132. http://jfl.iaun.ac.ir/article 597452 2c436e4bd407f9947f6b8e0b9c9372ff.pdf

Hamouda, A. (2013). An investigation of listening comprehension problems encountered by Saudi students in the EL listening classroom. International Journal of Academic Research in Progressive Education and Development, 2(2), 113-15. http://hrmars.com/admin/pics/1882.pdf

Jafari, K., \& Hashim, F. (2012). The effects of using advance organizers on improving EFL learners' listening comprehension: A mixed method study. System, 40(2), 270-281. doi: 10.1016/j.system.2012.04.009

Khoshsima, H., \& Sadighi Tasu, Z. (2014). The impact of task types on listening comprehension of Iranian intermediate EFL learners. International Journal of Applied Linguistics \& English Literature, 3(3), 97-103. doi: 10.7575/aiac.ijalel. v.3n.3p.97

Krashen, S. (1982). Principles and practice in second language acquisition. Oxford: Pergamon.

Lindsay, C., \& Knight, P. (2006). Learning and teaching English. Oxford: OUP.

Long, M. (1985). A role for instruction in second language acquisition: Task-based. In K. Hyltenstam, \& M. Pienemann (Eds.), Modelling and assessing second language acquisition (pp. 77-99). Clevedon: Multilingual Matters.

Long, M. (2009). Methodological principles for language teaching. In M. Long, \& C. Doughty (Eds.), Handbook of language teaching (pp. 373-94). Chichester, England: Wiley-Blackwell.

Long, M. H., \& Norris, J. M. (2000). Task-based teaching and assessment. In M. Byram (ed.) Encyclopedia of language teaching (pp.597-603). London: Routledge.

Mackey, A. (2008). Conversational interaction in second language acquisition: A collection of empirical studies. Oxford, England: Oxford University Press.

Mackey, A., \& Polio, C. (2009). Multiple perspectives on interaction in second language acquisition. London, England: Routledge.

Mendelsohn, D. J. (1994). Learning to listen: A strategy-based approach for the second language learner. San Diego: Dominie Press. 
Molavi, S., \& Kuhi, D. (2018). A comparative study of the effects of three different pre-listening tasks at intermediate and advanced levels. Journal of Advances in English Language Teaching, 6(1), 1-16. http://www.europeanscience.com/jaelt

Morley, J. (2001). Aural comprehension instruction: Principles and practices. In Marianne Celce-Murcia (editor), Teaching English as a second or foreign language. U.S.: Heinle and Heinle Paterson, Pat Wilcox.

Motallebzadeh, K., \& Defaei, S. (2013). The effect of task-based listening activities on improvement of listening selfefficacy among Iranian intermediate EFL learners. International Journal of Linguistics, 5(2) 24-33. doi: https://doi.org/10.5296/ijl.v5i2.3560

Newton, J. (1993). Task based interaction among adult learners of English and its role in second language development. Unpublished doctoral dissertation. Victoria University of wellington, New Zealand.

Nunan, D. (1989). Designing tasks for the communicative classroom. Cambridge: Cambridge University Press.

Nunan, D. (2004). Task-based language teaching. Cambridge: Cambridge University Press.

O’Malley, J. M., Chamot, A. U., \& Kupper, L. (1989). Listening comprehension strategies in second language acquisition. Applied Linguistics, 10(4), 418-437. https://doi.org/10.1093/applin/10.4.418

Osada, N. (2004). Listening comprehension research: A brief review of the last thirty years. 2004 TALK, Japan.

Pourhosein, G. A., \& Ahmadi, S. M. (2011). The effect of text familiarity on Iranian EFL learners' listening comprehension. Journal of Language Teaching and Research, 2(4), 783-789. http://www.academypublication.com/issues/past/jltr/vol02/04/08.pdf

Prabhu, N. S. (1987). Second language pedagogy. Oxford: Oxford University Press.

Richards, J., \& Rodgers, T. (2001). Approaches and methods in language teaching. Cambridge: Cambridge University Press.

Richards, J. C. (1987). Listening comprehension: Approach, design and procedure. In Long, M. H., \& Richards. J. C. (Ed.), Methodology in TEOSL-book of readings (pp.161-174). New York: Newbury House.

Rivers, W. M. (1981). Teaching foreign language skills (2nd ed.). Chicago: University of Chicago Press.

Robinson, P. (2011). Task-based language learning. Ann Arbor, MI: Language Learning Research Club, University of Michigan.

Rose, K., \& Kasper, G. (2001). Pragmatics in language teaching. Cambridge: Cambridge University Press.

Rose, K., \& Ono, R. (1995). Eliciting speech act data in Japanese: The effect of questionnaire type. Language Learning, 45(2), 191-223. https://doi.org/10.1111/j.1467-1770.1995.tb00438.x

Rost, M. (1994). Introducing listening. London: Penguin Group.

Rost, M. (2009). Teacher development interactive: Listening. White Plains. NY: Pearson Longman.

Safdarian, Z. (2012). The effect of stories on young learners' proficiency and motivation in foreign language learning. International Journal of English and Education, 2(3), 200-248. http://ijee.org/yahoo_site_admin/assets/docs/18.17211134.pdf

Sarani, A., Zare Behtash, E., \& Moslemi Nezhad Arani, S. (2014). The effect of video-based tasks in listening comprehension of Iranian pre-intermediate EFL learners. GIST Education and Learning Research Journal, 2(1), 008-017. https://files.eric.ed.gov/fulltext/EJ1062660.pdf

Skehan, P. (1996). Second language acquisition research and task-based instruction. In J. Willis, \& D. Willis, Challenge and challenge in language teaching (pp.17-30). Oxford: Heinemann.

Skehan, P. (1998). Cognitive approach to language learning. Oxford: Oxford University Press.

Skehan, P. (2014). Investigating a processing perspective on task performance. Amsterdam, Netherlands: John Benjamins. 
Underwood, M. (1989). Teaching listening. Longman. London.

Willis, D., \& Willis, J. (2007). Doing task-based teaching. Oxford: Oxford University Press.

Willis, J. (1996). A framework for task-based learning. Harlow: Longman.

Zohrabi, M., Sabouri, H., \& Behgozin, M. (2015). The impact of pre-listening activities on Iranian EFL learners' listening comprehension of authentic English movies. International Journal on Studies in English Language $\begin{array}{lrrr}\text { and } \quad \text { Literature } & \text { (IJSELL), } & \text { 42-56. }\end{array}$ http://citeseerx.ist.psu.edu/viewdoc/download?doi=10.1.1.679.8085\&rep=rep1\&type=pdf 